ら織

かに有 (1)

に参賀

乙与喜 家

た产左研

拿。者幃究

まは、は、お

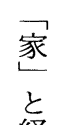

代を全よ的再担そ

的系体つ結編手規莱

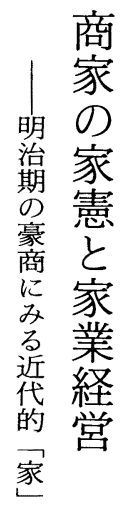

鈴親同族系営

なと資別と確が模

経本個し立経を家

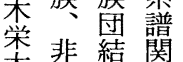

态親合係

も族 の

家別核営

のな系

精〈譜

神同意

家営をにて営拡や

が閔集担、次梠同

確に管れのい文い

立介理てこつそそ関

さ在すいとたれのすす

れさるたが盟で外る

いるとし示治も延研

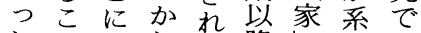

たどょしる。降高譜は

で具てが明、反係家

と系の

い譜共

うに有

葉守お

でるき

を同

規を族

範 明組

るえ体生そ的

こな活家側

と点い家精面

は变業神ら

家容経の捉

両学世営

の者るの代た

成はと側的が

員共、面継

資通もと続 現

格でう系続突

であ一譜あに

あつ方関る営

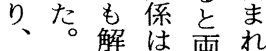

こま体相者て

のたな互のい

意少いに関る

味経し連係横

に営変動を牦断

おな容し概的

いい学て念な

てし余お念集

親精な儀り、署

族精な神ざ゙た生

あ体、ら、治家映とは

る。的経資期がしは采

は営栥以笨降どても系

全は年の思や関

継体口豪念一係

承は家商うし 致と

財家の層をててし経

II家成な゙ものたな営

資と員は礼となが

本しが系ありう不

の統点譜た点家分

轄的連の点年に

家さ和続を豪は結

てれ哲は有は明商どび

統いし、家ら家よい

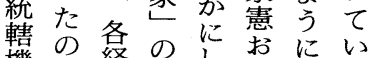

機で経成たる把る

関あ営員たび握状

へる統にと家势

の明轄よ考政るに

㷌治機つ若改こお

属治関てる。革とい

を期と経 考で概

徹登打は品る华

底場い家指ろれ京米

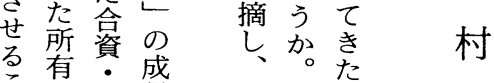

と有合蕆 そ本

にい多での稿で貝

にう会はこでは

よ新社ないをは経

るをれら。あ

汃共る加現つ

ぞ有と架実て

てい経人通家営

の

特

質

近念概掌々 て年体

$44(2 \cdot 2) \quad 102$ 


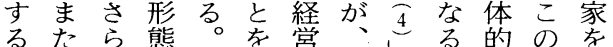

志同にで暖指が系と持に集主賀

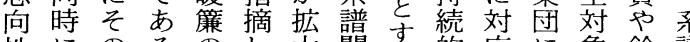

性にのるのし大関す的応に象鈴譜

が、子が系、し係る。な す即と杰と

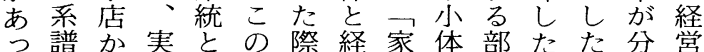

た関ら際はよ営し系分制の析

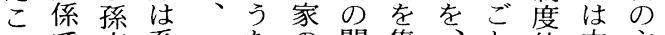

とで店系二なの関集文と体中主そ

をはが譜見企系連団制にし野対の

指な暖関同業譜に的度みと卓象分

摘い策 係族体関つ側的ら規でと 離

し経分と組は係い面核れれ定あ る

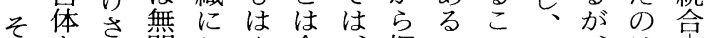

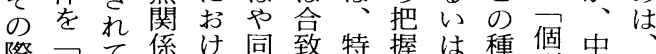

際家て 係 け 同致特握 は種個 中

に家いに分組な豙る度諸の㘧農

ラのう親家織い商点体制単、に

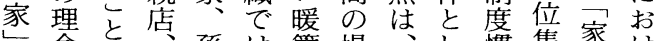

念をと孫は策場樌集家け

がへを本分なの合有て習団をる

ひとい占家い系に賀の昌とを家

と統て かとと統つと家複し集で

$つ$ 合いら同論驾い共合て 集あ

イしるる 店よ文存て、通家に制よ家でさ

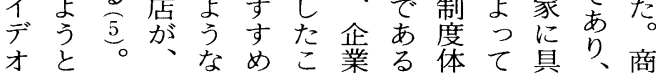

直稿ず然族 か すでしにはしは こはもあなか問 と、結りいし 題 かこび得筈し、゙ らのつるで鈴は 点加 3 あ木な 家をなっる。栄い をま口とし郎す 把之家指か沈 把屋向摘し 点 握系 の 譜側て つ家共 てと面いのの通 い経がる 精 精 で 。営あ。神神あ 体るこでしる。

関と指るつ

連を摘家い を示はとて 二 唆、述 はる実はな 切当 離で営人—

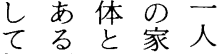
捉。はもの え本必当家
二でい族 親則のるしし家

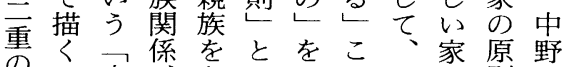

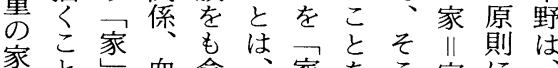
家と意含家をこ家に

意がの緑み経の—に族よ明

識で変関得営連三相構つ治

とき化係る体続重互造て 期 表るはに原が先のに售以 表現々よ則系の家矛原込降 現ろ家つで譜追意盾則奉の れう象て あ関求識しに公口

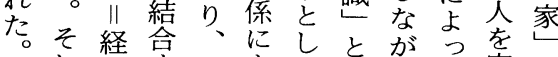
し営す新よて 表らて 家の てかる新つい現、同の変

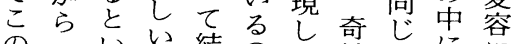
の家い家結 $\frac{7}{7}$ た妙人にに 三家 原川家び 。 の II 則家き中そ調を摄い 型血で族 、野し和家よ統よ が縁あ構系のて 統の方は

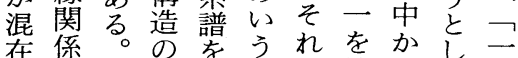

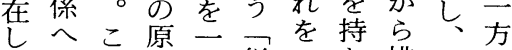
ととこ則に従学排他か いい加斯来媒う除方ら るうらとるの介としかは 状理中は限家すしょら従 態念野、りのるてうは来 が型の 親非原もいと新の

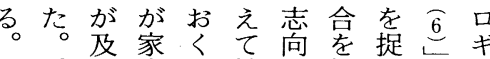
系ば憲こ拡性捉えと!

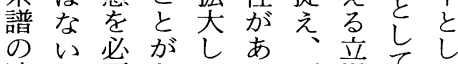
連経要必たつ両場てて 続営と須場た者にる自 が学しと合こがたる。覚 中をた考もと分ち 一さ 核只え齐離なこれ にい的ら系示し がに あか背れ譜唆たらに多 つな景て 関さ場も訬

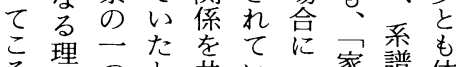
そ念つ琶共い家譜体 経では解有る。家と経系 営統こ率さ釈しと経営さ 体率これいれし営がれ はしにる人故て体連た て 指の物㧧なを带規 家い摘でを経お方し範 でかむもも営経旦た と

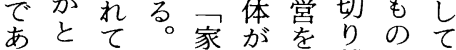
りいい確系統離と姿 得うるかに譜合ししを た点系に統関してて あ ので譜、合係てそ同ら であ関豪しをいの族わ あつ係商て超く統団す 
書少手般家契

な堅に憲機先 (1)

とから豪は意述家

てず風のぜ罚心憲

残あを家、がた制

しう守定ま 関定

たたつめた系心契

とと来とをと基機

のした考契経基

理、家え機営き

由豪でてとの本

を商は、し関稿

経が家口が作傅で

営憲伝成け憲

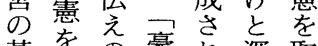

基を系豪れ梁取

盤口処家たくり

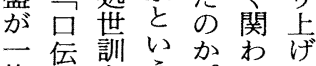

族えをう。る

族文持ほ有て理

党のちど賀い笛

のみつのはるは

上なづ家它を家

ひずたな憲に憲

ろすもくをあ制

が文ももこる。度
か立外行しと過経で経家機

ののつ、が程営有営家笌確

試要た明本を体り体でなか

み因豪治稿捉全得ははつに

のが結どを商正課直へ体た家なな。明

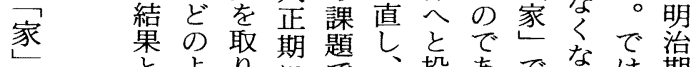

とょりにでそ投あでなは期 てに宁あた影ろあうた非降 近家る。結れかただ親の 代家。のそ果た。の艺族法 のし経再こ現の同でろに制 家作営編で杂だ族あるか。多度 は角势確稿くう市市核でそ委非

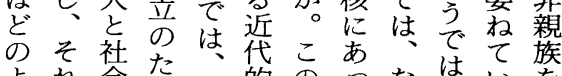
よれ会め系的のつなはいを うに情め系譜家う系ぜはた経家 な対勢家と譜家う系な譜ど。経家 質る変政経の豪関晋後営か を花改営特商係よ確はら 持家と革の質のは確は排 $つ$ い担を家家どに認明除

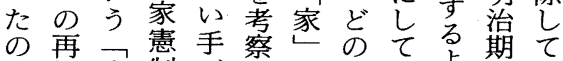

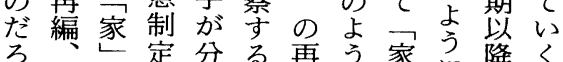
う確内定分る再う家離こ谝に契

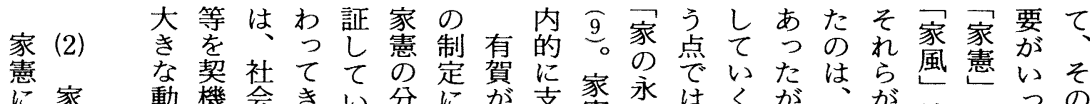

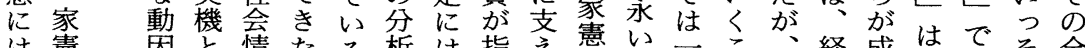
は憲因と情たる析は指え制存致こ一経成はで全 马種あでし勢こ

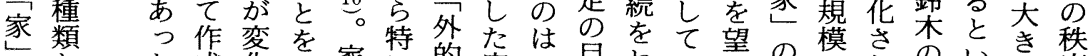

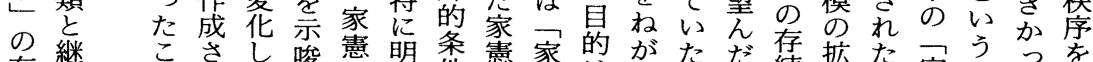

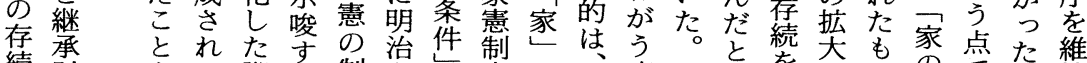

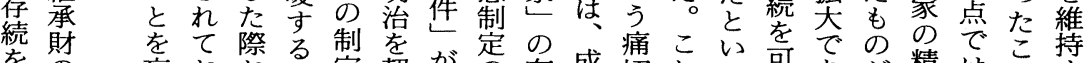

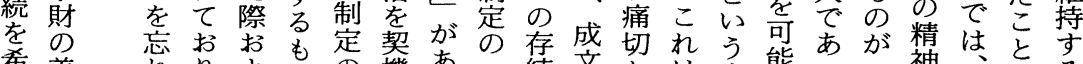

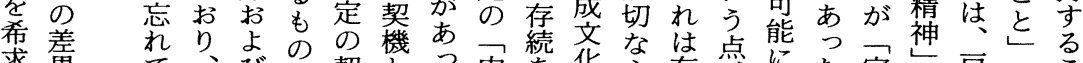

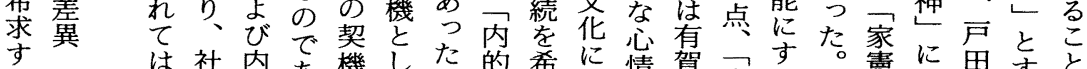
る

と

う

共

通

性

同

時

に

家

の は社内機した的希に情賀家るすた憲に田すとと

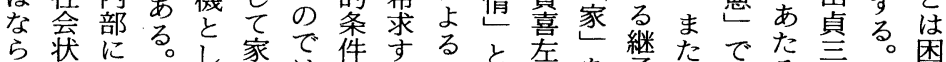

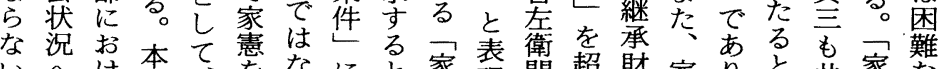

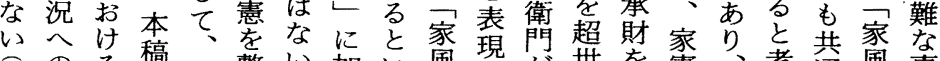

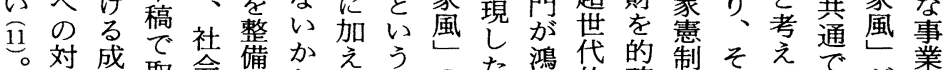

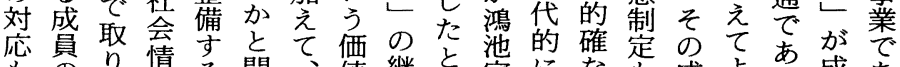

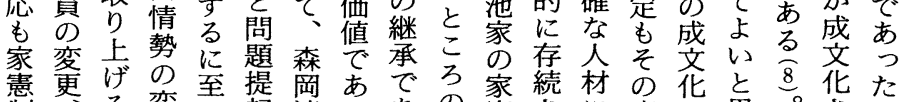
制更る変至提岡あでろ家続材の花と思。华た

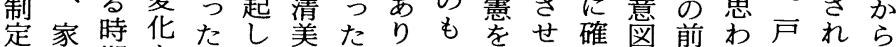
の督期も経、养。の分た隻図前わ田たら、 一のの深緯本、 そで析いに様とるのもそ つ継家くを願家れあしと継々ながいのの 
点さたとの重開とな要とのこめ定行憲も明説限続

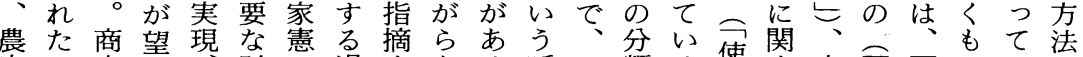
家の家ま財の過すもる呼こ類る使す店家近のみの がはのれ存及有程る。、称こでよ年る運家近、訓差

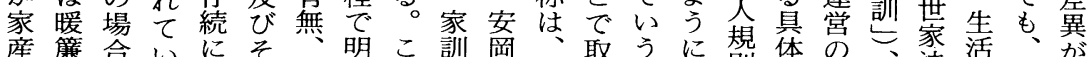
とに際の家らの加実りと則的心相法財観

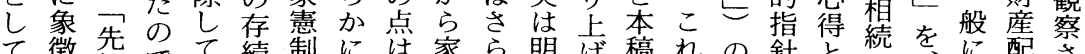
て徵先でて続制には家ら明げ稿れの針と続を航配さ のさ祖あは方定し本憲に治るでら五お分家関分れ

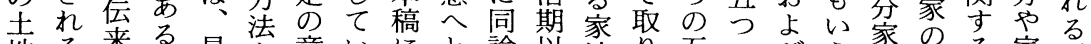
地る来る。具意いにと論以法り五にびう家のる家る。 を家のそ体階図きとい文降全上分規べど管精長そ 最業々机的層種たつうでに般げの類則き家理神のこ

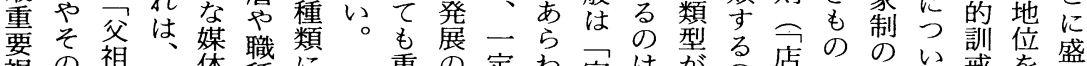

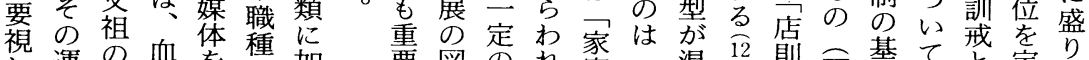
し運の血を種加要図のれ憲孔混望則 基て裂定り

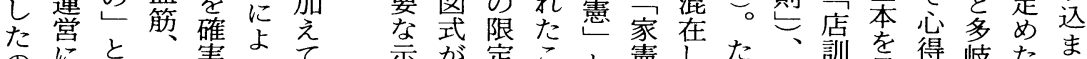
のにと家策って、示が定こと憲しだ奉訓を具得岐たま

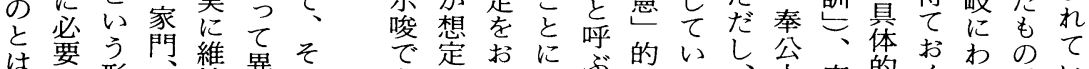

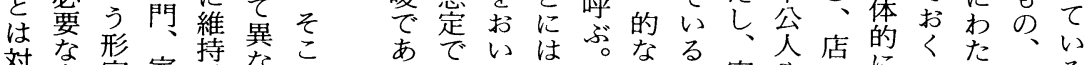

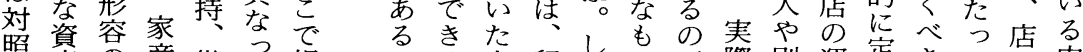
照産の産継て規のる留かかのが際別運定きて占内 でで下や承い定でので意しが事は家営た教い経容

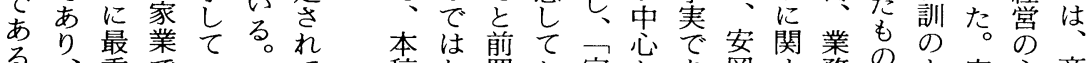
る、重でいへて稿な䈯お家とあ岡す務のな安心商

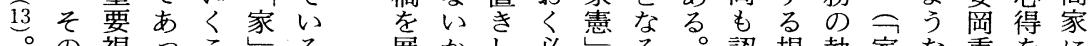

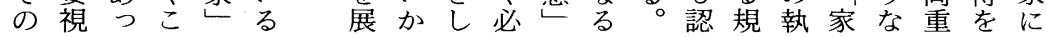

だはる経設にへり二福は

と、経営期対と、う罵どで(3)

す福営の以し移創に正のは

れ島方類降て行設分夫よ家

ばの法型も、、期けはう継憲

なう持妿議岡独は経財規財み

ぜよつつ制清裁独営閥定はら

そうたので美制裁が家さどれ

うに意指ははを制あ憲れのる

い同味標な、とがるのてょて

う族がでく商り み程考いう家

過協問は独家続ら度察るに电

程議題あ裁でけれ拡かだ継の

を制とる制はたる㚐らろ承経 辿乞ながをな言がす茼う菱

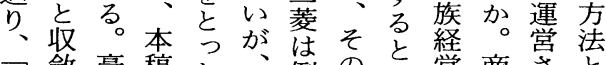
家斂豪稿た、例の協営商さ兴

家し商で例真外場㧝の家れ変

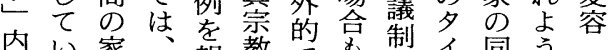

内い家報教的毛制イ同う

外く憲明報等で并を等と

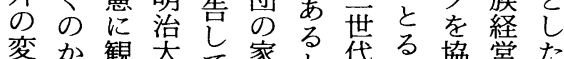

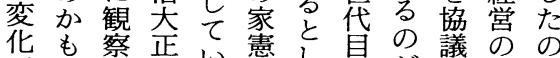

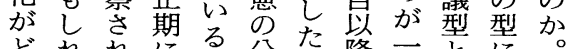

どれれにる分た降二般独に。

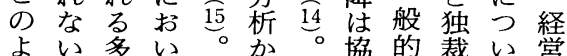

うが様て同らこ議で型て方

な、性あ族創れ制あの、法
と信はにしにけでこ てがとついう継るよ 必付してたて承。う 要随て承家財とな でし、認制業たい継 あて株さ度、りう承 つい株れ体暖得の財 たた、た滞たはの のの二財のがの、差 はで三で基大で継䔬 ほあ前あ盤切は承と かる前つとでな財森

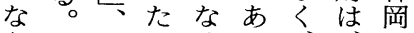
らこ二こるつ、、の

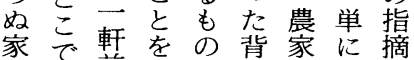
産取前着で景に人し とりと過あにと々た

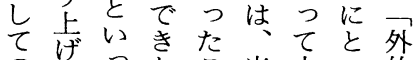
のろつなこ当土う的 資豪たいと該地て条 本商公。 社 的重件 家等な的さ例さ会大要切 業場権将に況で考密 で合限济学 あ家社れ該でり、れ関 た侌ら社成商たわ

\section{4 (2・5) 105 社会学評論}


い運の借規のは先七なれ取

て営強り範類、先七柦りり家 (1)

もな調れやは相祖三家明上憲

ぞ新ば精多続規こし治げは近

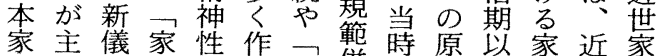

- な停風をら家隊の型降々代憲

主項止説れ家家ともで以垫

家自闪々ての務長な的前特

中と同確こい系高る先学

心し族立とる譜正平こ祖明以

的て・无に亩に徳にとの治降

で共本あょ祭関交よが遺期と

あ通分るるこ专年つあ訓以で

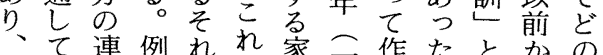

本い带えぞら憲七成。乞らよ

分る。底れの家芜さ例て家う

の。日、の家み六れえ、憲に

意相常主憲ら爷たば家を異

識続的従家にれ制今憲持な

をや生・共な定宗三心うう

わ分活本の通い定管井冒こた

き別嫢分理しも遺で䫒との

ま家範関念ての書はにがだ

えの、係、いのが $\overparen{16}$ 、揭多ろ

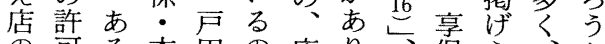

の可る本田の店り、保ら鴻七。

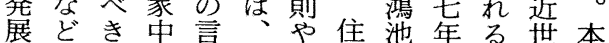

にに店心葉行店友でつ重の稿

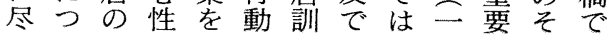

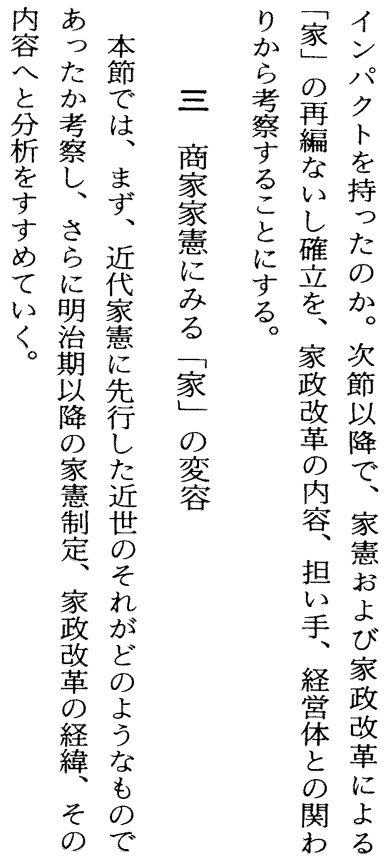

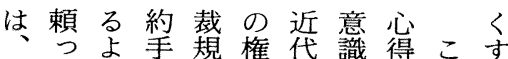
ぞてう続定限で迹のよ のいにきがとは奉店よう よたなを新い精公則う精 うのる。取しう神意和に神 なで。形性識使近的 状は多入設でに体角世訓 洗方机同つ体人面戒 下家のたら族い面規家が で家近れのて意則憲多 この憲代る権は識なは岐 こ存の的こ利基強ど、に う続冒なと義本強の安わ い綂頭法に務理さ各岡た つまに的なを念汃人う たま記体る。琞に宗の指て 近なし裁。確折㙓精摘訴 代なと整法华込勢神卞え 家な あ整的し人的性るる 憲なる制い形、家が家訴どれ

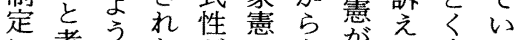

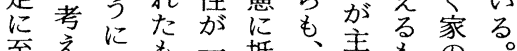
至之坻主主も㐬 ら 20 の貫触財流の管 たて旧多てた颜あ名理 かい慣多打場有る゙啠店 た自り合有が、䓬 でに毛契制分 处分裳 
をて安材にすの込力はのの綻と持共先可りりた有

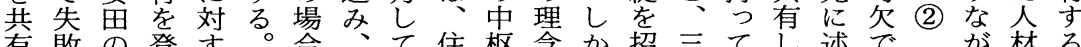

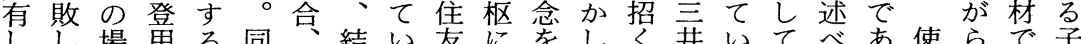

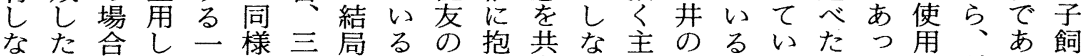

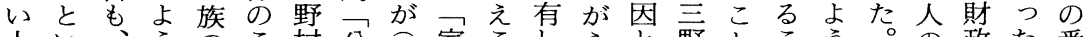
人い、うのこ村公 22 家こしらと野とこう。の政た番 材う中と反との私公告な彼さ村がとな彼登の。頭 に興し発は死混明をこいられ利要よ危ら角維家で 経件のてや、後交治我と、のる左求り機は...持々は 営が祖一 24 小给我か従登が衛さも、を、維市はな

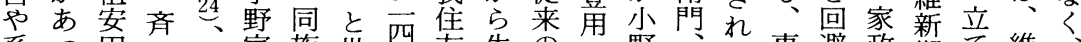
系つ田に白家族批年友生の嫁し野住た専避政期て維

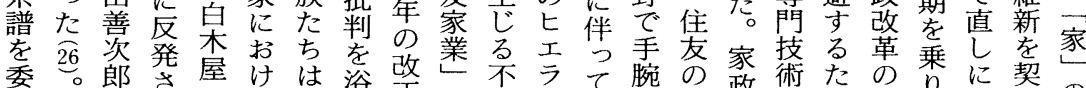

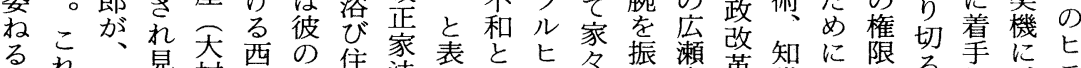

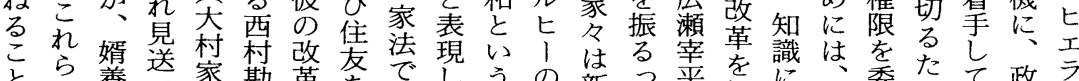

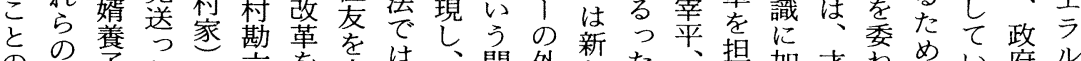
の事子たが六を去は、問外新た产担加才枚めい府ル

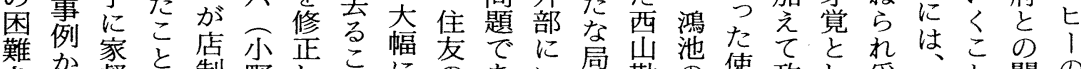

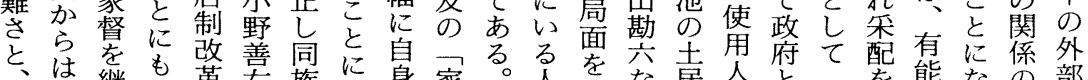
そ、継見革右族な身家例間迎な゙居を古家をななの部

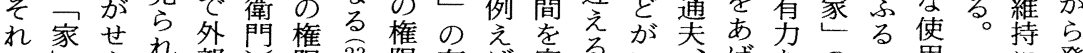

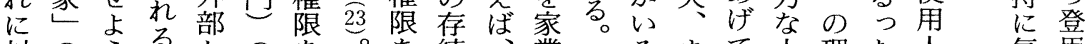

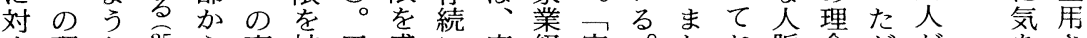

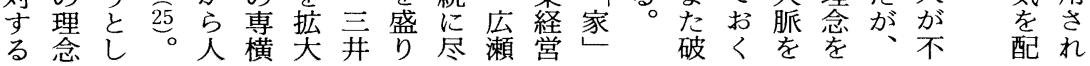

ある同はと三の至明たは改政して、憲て存は家は危

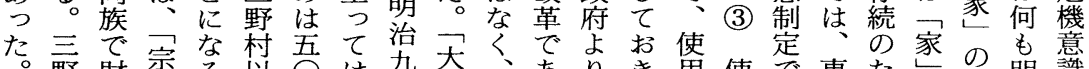

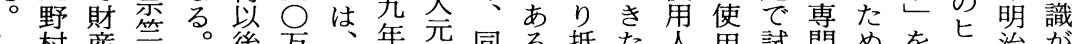
し村産遺。後方年元同る抵た人用試門めを治が かはを逼明三円三吾改苗。当いと人み家に滅高に窥 し、共畫治三に井苏愍加銀增。系とらにはほフ始え

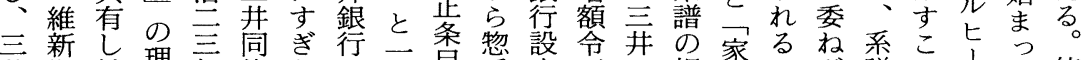

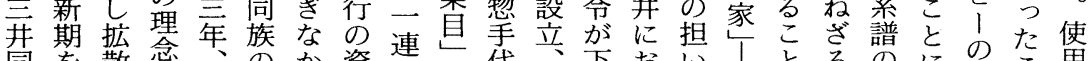

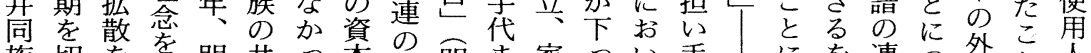
族切を復明共つ本規明ま家つい手」に迋つ外と人 にり防活治同た金覞治で政たてと文な得続なかでが と抜止萿西所。言則艺の改際三の井るなががらは経 こ记さ酉有こ はたう三の制二方定々とは抵がど合情要か难がお

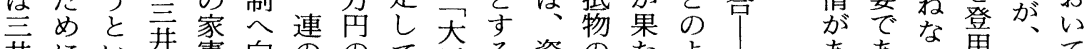

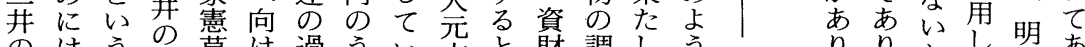
のはう寞け過うい方と財調しう… り、りとし、治あ

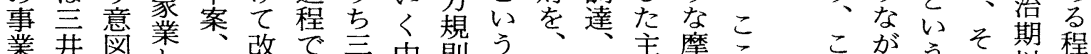

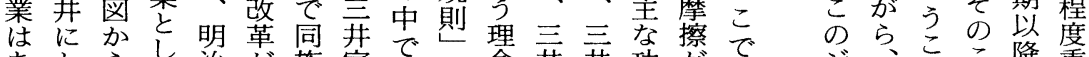

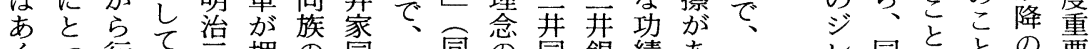
くっ行て言押の同三同の同銀績あ三レ同どとの要

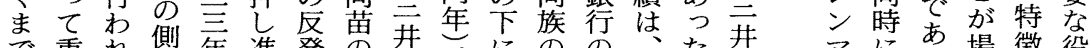
で重れ側年進発の开、にのの銀、に开場徵役 要た面のめ垶銀つ改み設明のを経る。合は割 家なも強家ら高義行盟革の立治か例打営家に徉担

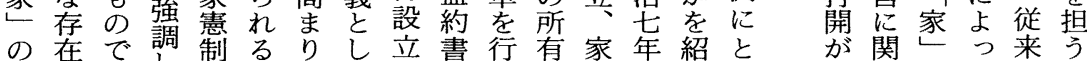

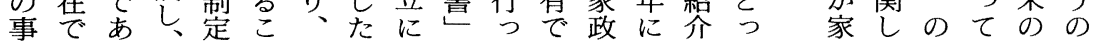


協岩みよ鼻回集家く性を要のにを制期定三票村族業 議崎がう身避中々、尔許で存お指が以に野 (4) はので

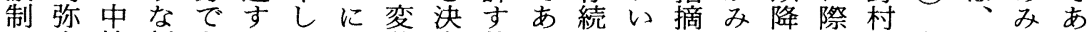
は之核新あるたは革定状り発てしら財しに危同のり 助に興る点資必期し況、展もたれ閥ては機族もも、 後市の場に本ずにたのその危がる化自独脱かのこ 述岩り、家合あの改は直のた機、のし身裁出らでの 守崎、々摭独つ無際め回明はてに的の一あ場 る小その例た散者裁ま热変避治創い独なた斉る合 継弥の家え。をが的り㳯の維設つ裁権めに心゙の 承太家長ば従防いな之家! をた新期た的限の反き言 財の長の施発で井 摭場が場後てしと定代の! 儀個にみ家権集裁さあの 散合経合述、、い機貝存シな人㧺でで限中とれつつ

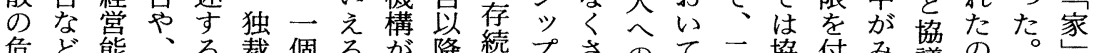

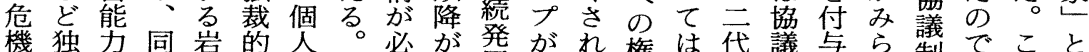

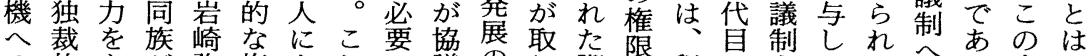

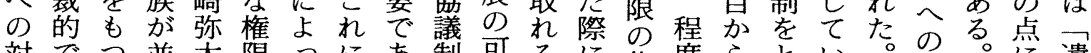
対でつ並太限つにあ制可るに集度らとい。移。に遺

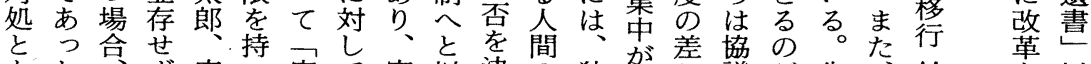

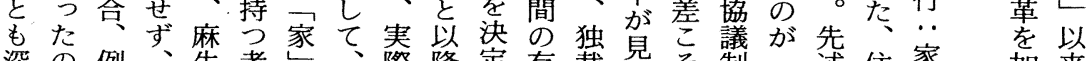
深の例、生者名、際降定有裁見空制一述住家加来

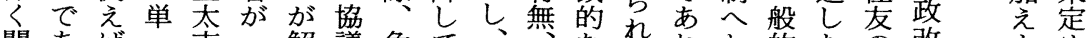

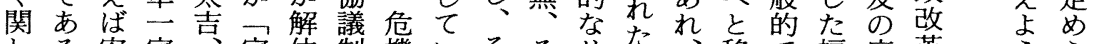
わる安家家体制機いそそりた。移で福広革方ら

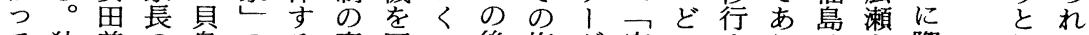
て独善の島のる意回の後権名家の方り、㐫際した

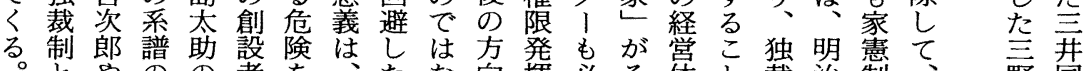

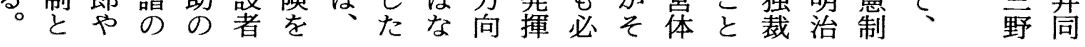

策てと戒も合たり個と念者しない必く成い従 でいえのワのの、々つをっ、つたずるさ諸来 (5) ある㷪み家制で同人て組商家たたじれ賛の つのがで裁あ時に、法家ためも明た範々民

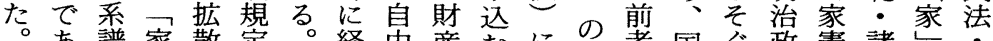
あ譜家散定経由産む償に財者国ぐ政憲諸家商 る。継をの設茾営に処はか関原民家わ府に法の商 協承統危け織分家いてを法にいよ法いて念へ 議し率惧ら安をさ方活のに抵、りああにの 制てし架れ、思いれの問近よに触む提くつ直対

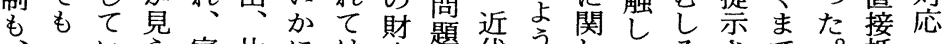

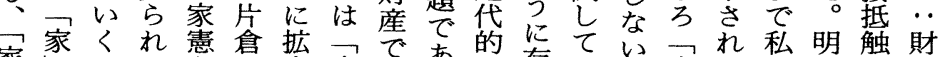
家家これる憲倉势家であ的存い限家た的治等財 のがと。国家ししりた会続えりり法で期た難 の滅がも家憲よのり、た社さ悇りの制は期の

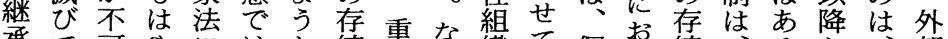

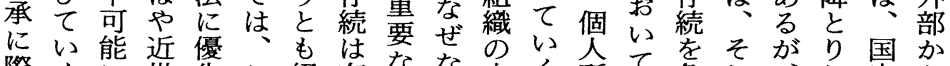
際くに世先こ経有な継な中く所て危れ対的家ら しこな家さの営り継らにか有対うぞ整けにの たとつ法せつ体得承ばどと応くれ静民よ人 危のてによ家はな財っのい原がさの䜅法う材

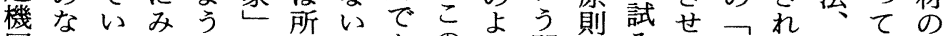
回いるらとの詮とあのう閏とみる家た商提登 避よとれし掟马考つ時に題すら要的も法示角 のう同たたに家えた点つでるれ素のの公さに 一配時精。反它家あ民る理が布れ加 つ慮に神こしでれこ各勾法こ含念現以た立 のさ、的こたあてれ家の、、にと的降新て 方れた訓に場つおをに理後対にではて作し 
をてに同ル出一を

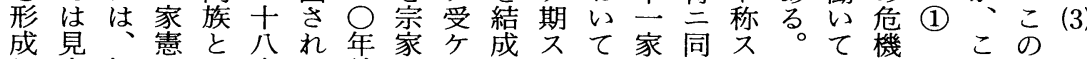

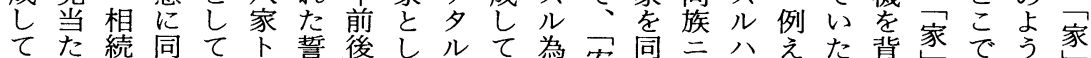

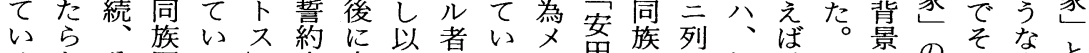

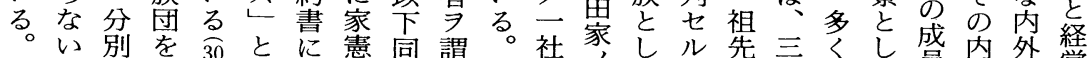

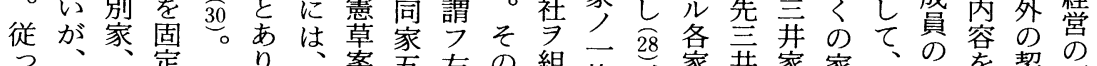
て住同定り、第案吾左成織族家萣憲憲家固具機再

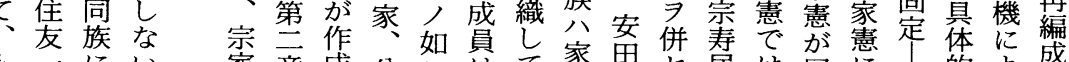

も友族な

よをす久

り頂るに 家点規も 数定嫡 を、流 限 ピ空䍃

すミ袁 視

るッさす 必ドれる 要型て 傾 性のい向 がヒるは な エ限あ 汃ラ

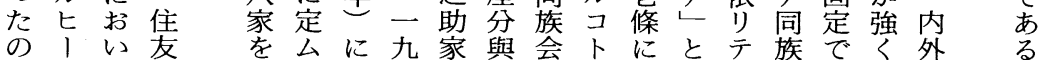
連族杂交第安安基大等苗第頭経序見て

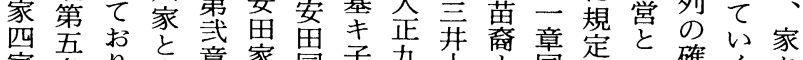
家条り、定章家兽子杂等章定と確く々

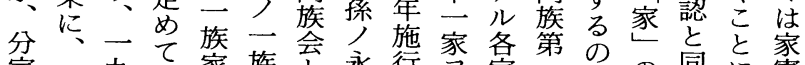
家年九家族令永行 士片三る格卜名遠の総及条は再族す害

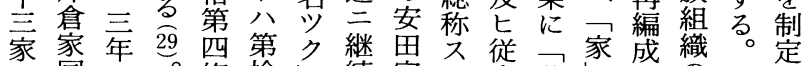

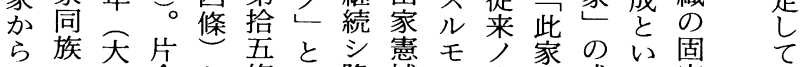
な芷倉と條し隆補, 家憲成う定い る次二で焦意门 十条○は善財、第三製於意| の 八に年、旁同ル壱テ依テ固が、.

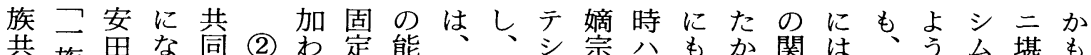

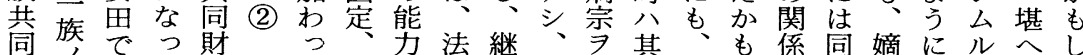

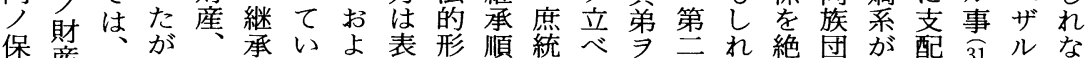

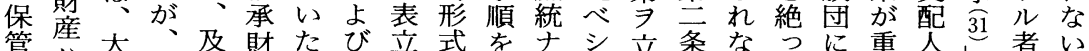

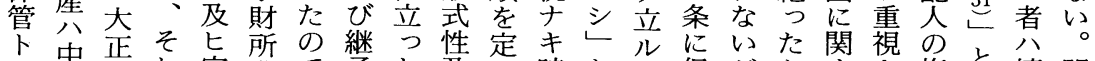
ナ畍八れ家有で承た及め時とモ但がと省さ権と嫡明 シ祖年以産のあ順問びて八規, し、あるれ限い子治 各先の外光確る。題血い正定卜書分り規たがうト百 自当家は言認。明に縁る系し、古別、定の増項雖四

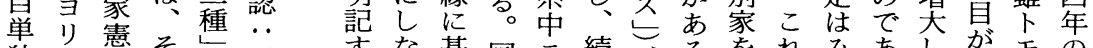
独継憲そ補のに兰な基同三続、るをれみあしがモの

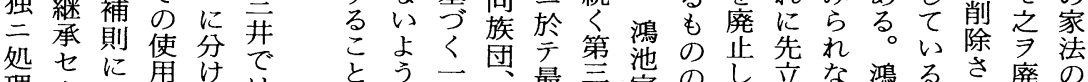

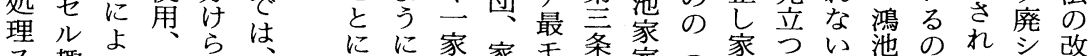
ス趣る支れ、にに家家禾条家つ家つい池の想㳊 ル旨と出机同は㢳督近で憲嫡を数明がのでて 次正

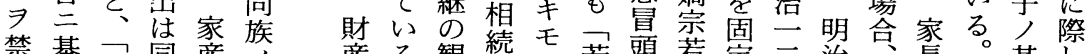

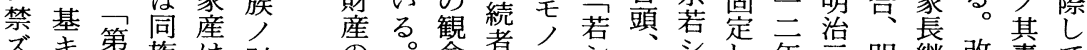

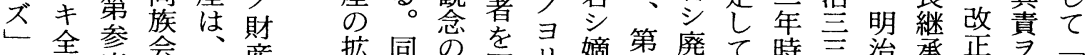

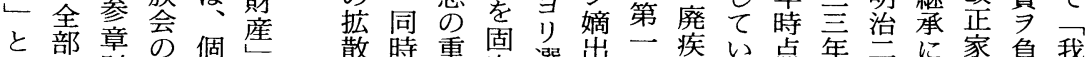

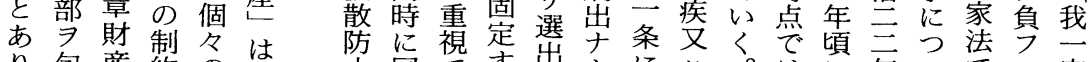
り包産約のは步同です出キに公。はに年いでべ家

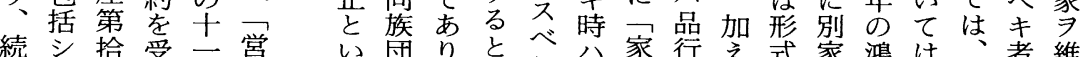
続 シ 拾受二嫦い団りと学家行え式家鴻は、者維

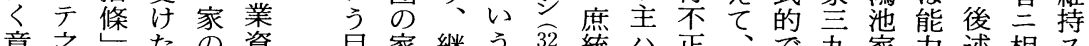
章之貝家継う統公正資で九家力述相 でラに、 $\widehat{33}$ 自産的数承こし 
滅協産の自 $\widehat{36}$ 二金り、配 35 兄産家先に持田二

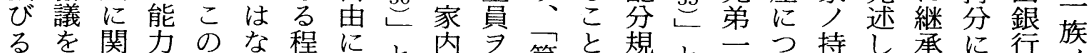
るを関力のな程にと内第々嫢と二つ持し承に行族 こ必しはなく度なと事蓄第を定と基う致い分たさつへ財 のとは本に家認なっ係積条禁はすり結は比譬たてい出瘏

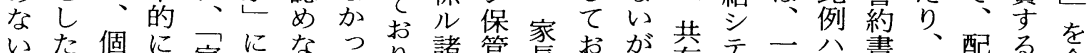
いた個に家に属がたり、諸管長おが共デ公書子配る

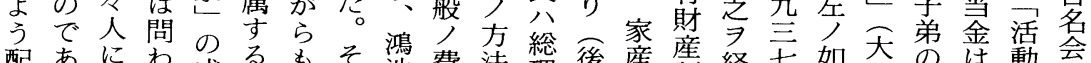

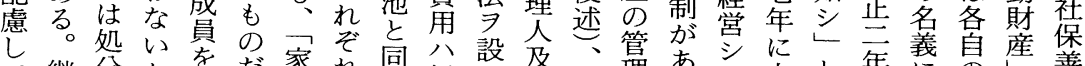

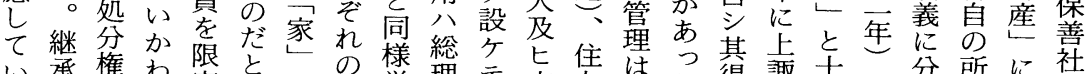

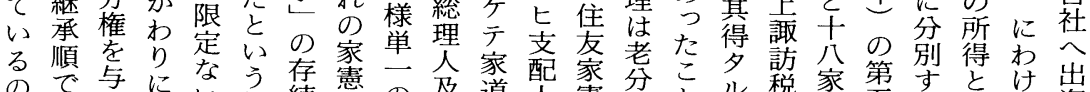
で誰えにい規続に門の及道人憲にと分に税家第するとけ出 あがず家固定に洪家長支鞏詢は委が资務配士こる家す

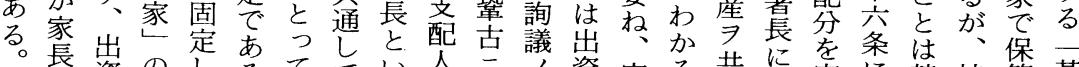
経に資の継てる。て重てい人借上資家る。共提定に禁持管基

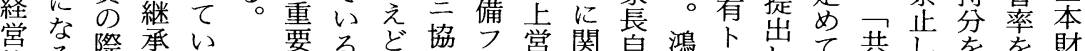

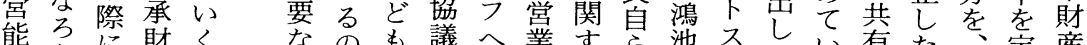

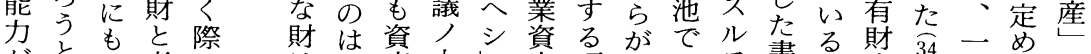

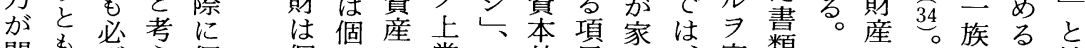

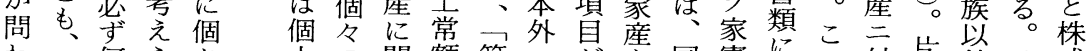
わ何ら々の関額第三名を同憲に片付片外々式 れ家られの財し たし加盛も産て定二干条右間セ二有族はも保社 のがの資員のをは厶条, あ寺のリ族財各は管安

員加人運成使分任条定に

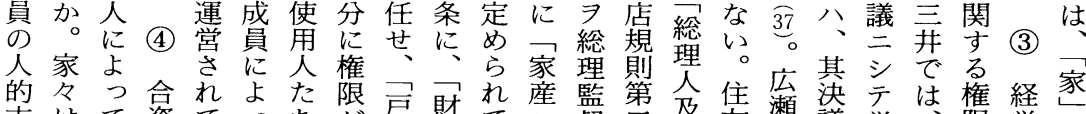
支はて資てっち が主既て公督等及隻瀬議営篗営

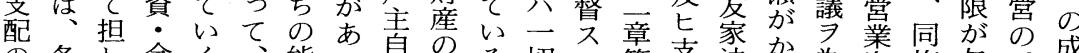
の各わ合く、能つ息管る切会第支法加為資族与委成

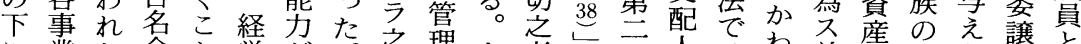

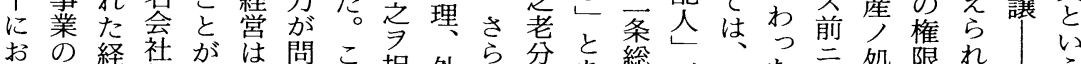
おの経社がは䦖こ希能わの担ら分外総が住た重分限れて使う

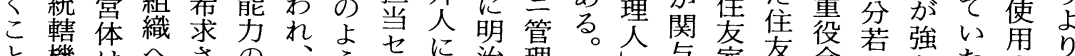

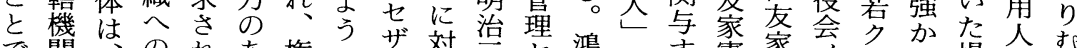

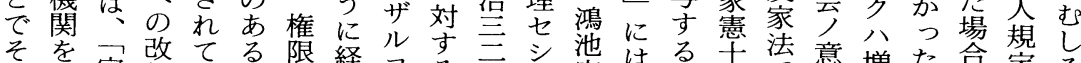

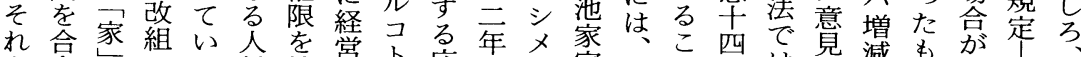

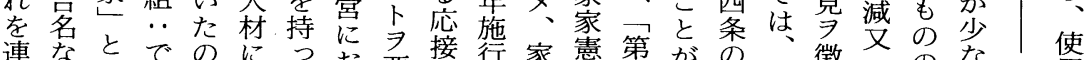

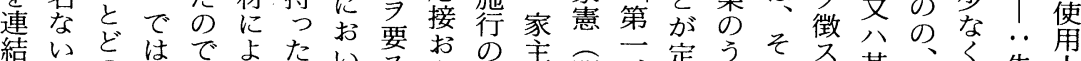

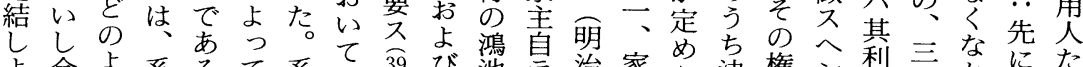

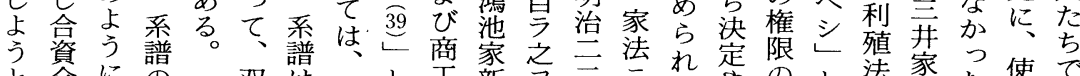

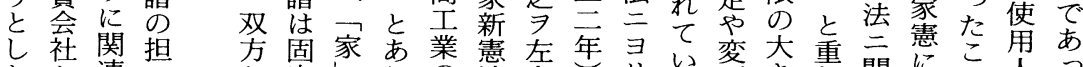

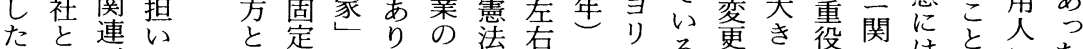

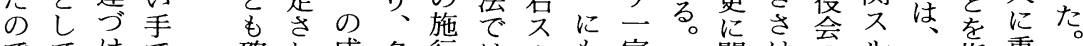
でてけで確机成名行は、も家さ関は会ル司指重 あᄀらは実た員実州、全さ守言規事同摘要 る家机なににでとを第得第部らるう定項族しな

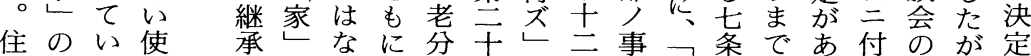
友成た用、のい老に三と条務本にもるう決、に 
型はにてす全ち守

の際いのくはり 明 (4)

三筑しるは一、続治

井豊て 茠つ自け期新

家岸旧社のらて以興

憲坑家つともが行降の

に御の家いの嫁

後家憲のよと家へ台々

者の嘉存りての先頭に

を皇壬続口思創祖てけ

単つデ方巨念設のきる

家貝と法大竖家新系

型鼻しつ家いあ興と

の家てい崖るるもの経

住といてで。る旧家営

友麻るは市例い慣々

家生も、るえうもに

法家のいとば自なは

にをがくい、負い近

そ対あうう岩貝。世

れ象るか点崎満し以

ぞとがのを弥漸か来

れし、家は太方しの

類て、例憲つ郎家そ旧

似、えできは家そ家

性前ばはり、正のと

を者畠そ打自と創比

見を山のち身経設心゙

出同秀制出㤎営者て

し族樹定し興をた

で創し明解他家と

あ設て治体方家い新 (5)

つすいをの創う興

たるるら待危そ創社の家

し能とず機れの会々に

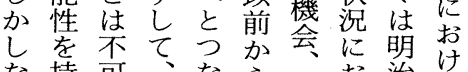

な持可、なら可扔治る

がつ能系が歴能い期系

ら、とに譜っ史能て、以系

冒うつ継の伝は、は台経

頭こて承で統明め頭営

述はたとる持治てて

た確がい本? 期創き個

よ確系限稿家な設だ家

うに譜らでの?可述乺

に危のれ取担て堌にた能た制

業を抱い蕆卡手艺なが市

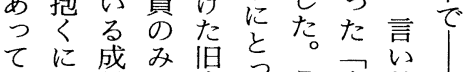

のは員で家てこ家替

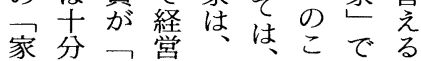

な家をすっとあと

で要を運で家は営に盟
人の承関四治で会る就部の

でで財を五兰も社。任機場 はあを介年六同を言し構合 なる。保し、年様設并て立は始住

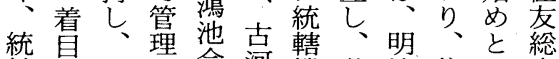
轄守そさ合河機共治住し本 機べのれ名合関有四友て店 関き財、会名の財三合值が でこに系社会法産年資系大 あとよ譜天社人のに会会正 たはてさ連正明を华有开社社古 こ継運続治行家出直に と承営性 年四っ財十資系住 で財さに年四て閥二は銀友 あの和よ年い莢家、行合 る。所るつな心る尗のすす資 有こてど合例事みべべ会 主と結で拿例業をてて社 体にばあ名えの出住のに はよれる。会ば統資友社改 ○経安三轄社員族に長組 家家家営思菱関とに住れ 体保合とす限友た のでのは善資しる定家が 成あ成社会た言さ長。 員り員統俞社。茾れ友こ 々た継機治㫜家名いが本

に設義と独た系助がこて あででし新裁文萣特うい るああて興制両血の徴とる のつつ合のに家統配です はたた致家つと $\Rightarrow$ 分ある

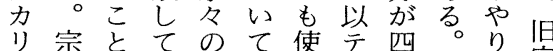
ス家がい場は角家○貝方家 マによた合山人督\%島での 的中り。岩に相あであ家 創心明そ系崎権続り、はるる家

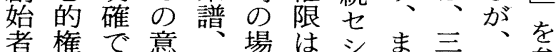

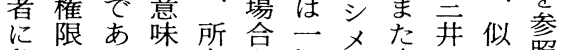
象おるに有も切決麻のて照 徵よ。お同委決生財はし さびまい経様譲テで産いつ れ特さて営でせ之は制て? る権にラのあず爷模も自 家付箅家三た家乱家模占ら で与蹬のが。長哥第し宗家 でし與発家息方各な家家 つがこと怔にら心を たらと経の独年方的つ のもかが営創裁し家創でく

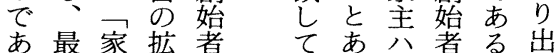
るも称貝とし 中核創同心 る。宗島こて 


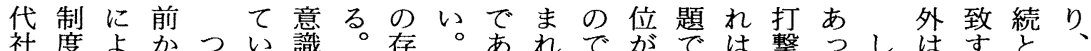
会につらまくさ継続所るるあ個あ国とたかなる経そ がよてのり、のれ承に有。こつ人る家はもしかこ営の

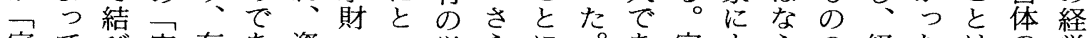
家てび家存あ資へつ単らに。あ家よらの経たはの営 に結つを続る本のて位になこる々つな多営と存は

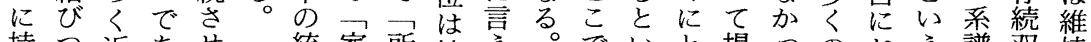
持つ近あせ統家所統え。でいと提つのおえ譜双持 つく世つて轄し有轄ばこ、うつ示た家けるの方さ た明のたい機へた軮、練考てさ。憲る。継がれ

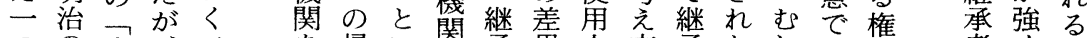

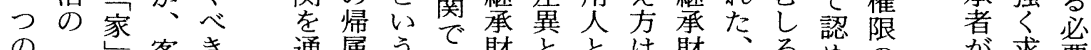

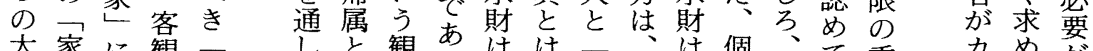

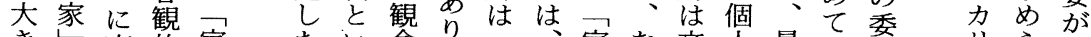

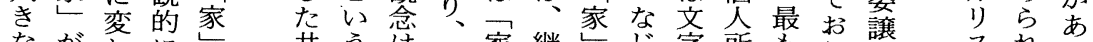

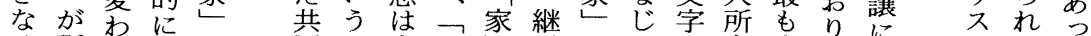
イ誕つみは同こ大家承のみぞ有大り、につ文てた

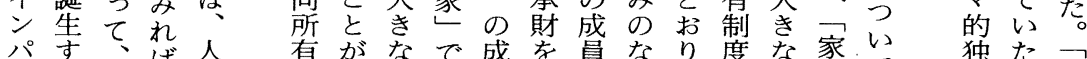
パす、值がなで成を員なり度な家、年独たい クる听精々、意あ員所をい、に問しで裁が家 はで有精意神改味る個有分、家ぞ題の存歪者々゙その あと性識形て持きがるる只産対別続確市れ存

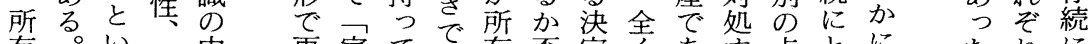

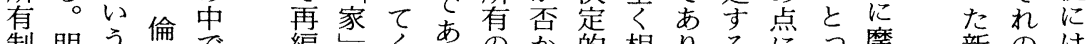

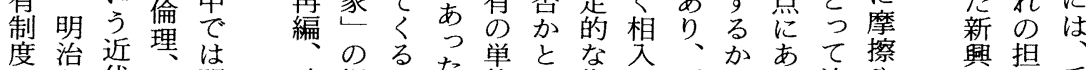
でと代亏明確担こた。位い指れ所とつ決や のい系 あい固家治立いと售ゔ標な有いた定㲘家手譜 るう有風期さ手に家はこがいのう。的念令がの

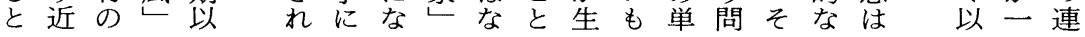

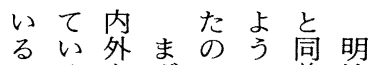

こるをずでに義治 とこ問、あ実に期 がとわそろ現考以 優よずのうさえ降 先り有実かれらの さも能現。机豪 れなな商 た能人過たいの 。力材程結た財 系・にに棵こ閥 譜知委つ と と化

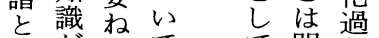
経がらて、て明程 営あれま はるたるら こ と、こて

点政の

点政際く。 おと等 い家経

てつ宫

はな理寒

分離を念は

し 持 共 系

てつ有譜 近 5 程 代吕枋 のにけ 家れ経 は㤎営 どさ拡 よて は

特こ家 をはの 持 ど発 家さる なの 实
した家資にこ使財る。しせるず言

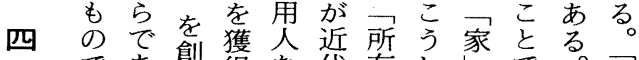
であ創得な代有し它で。家 系ある嘕るい家制近成な家家 等 の 分 継 承 を 介俱など手でい続につうたう た の 統 命 降い段あく続属たの新

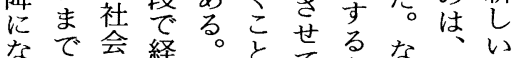
うも桨営近がてももぜ経観 て非況資世不いのな営念 は常の本に可にだらをが じな中に扔欠継尔 め困で足いとはた承他在 て難、るてなっか財人し 顕を自だはつ家らはとて 在伴由け昆仮た。の市決任る 


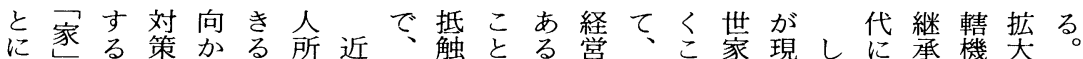
なのことらと有代経すで。堡従と法れかな財関はこ

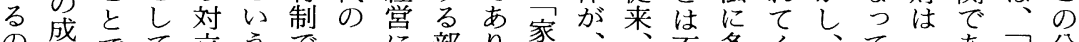
で筫で韭立うで考家携分り、部家、不多く、て家家

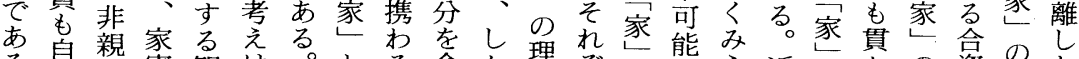
る自㮢憲観は、をる含か理ぞとと能再かの資のた

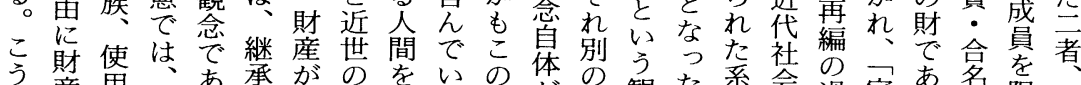
う産用、あ承がのをいの体の権た系会の家あ名を者

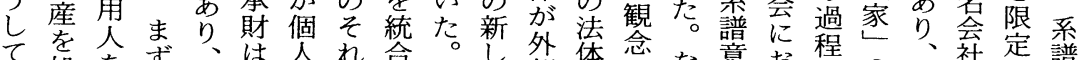
継処をず、は人㭘徉い部傃念な意お程の公社定譜

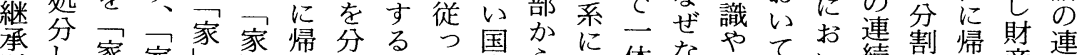

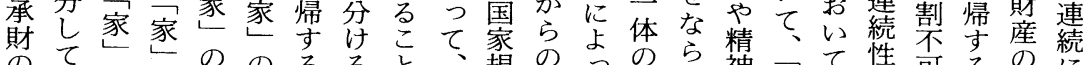

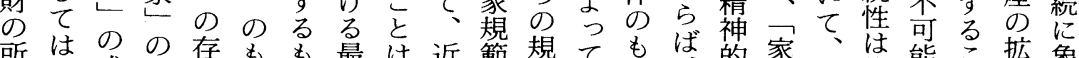
所は成成存もも最は近範規てもば的家、㴰こ搪象 有な員員続ののも不世は制規の民訓同維でと散徵

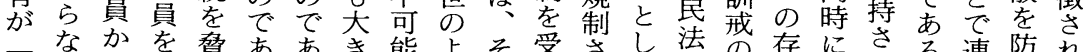

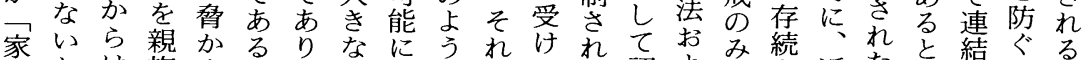

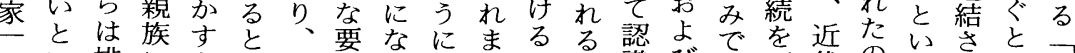
のい排にもい個茵つ—でのこ識びう可代のでうれと家

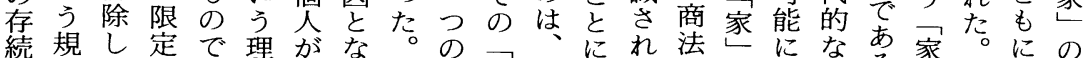

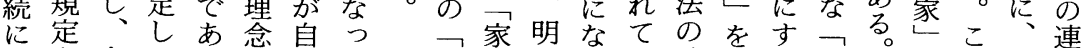
とをさたつと家菭つい公統る家ののの継続 う設ら上たはにの馀期たた布率に里方承と てけにで。処はの観以か系にしはの念法財事

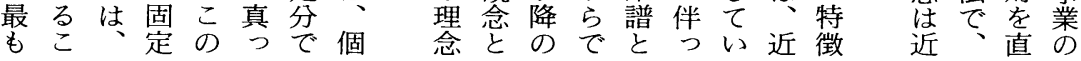

たと二は踣 な来六百有 抒の六杂賀 有系、家の 賀譜一族家 鈴と六制 概 条究度念 家二收小化 の著译作 変著や制系 华集々度と 捉 VII 旦有機 方末に賀能 に来お喜的 社け左連 い一る衛帯 て二先門 は九祖著と 别六の作関 米な念 I 連 禁を゙家政に 代参の未つ 照系来い 家し譜社て
財をなとる。ここ家触以降継垈世近としと重 所つ值うこ任に皂がなも承ののうく譜な 有てを排のせな契がい世財马意るを事 はい持他よよる機所よ代が家家味の連項

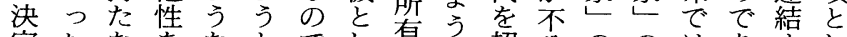
定たな的なとでし有う超分ののは市禁し なこ的くな持特継るて方家え割々結々る。るて

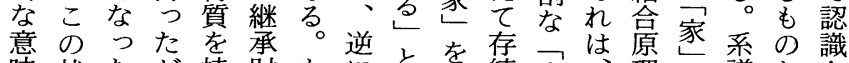
味状たが持財もににと存続家档理の譜とさ を洗近、つがは所い存す続す継を担をしれ 持に帒他近々や有う続るの手暖担超てて つ扔社方代家経を手さ制財財策手え方、い てい会での営媒続せ度での㲘手て統く。 いて、、家在が集をて体あ共媒意拡轄。

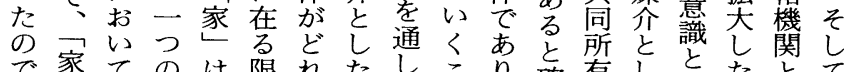
で家て、はは限れたしこりり確有しとたとて あを分家、りほワてと続㑇に求経て経し事 る。捉分家二方々拡家 のをけ認求経は㿥て実

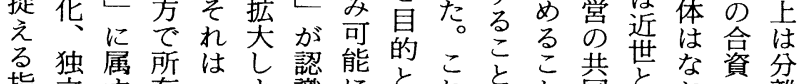

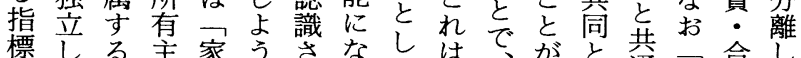

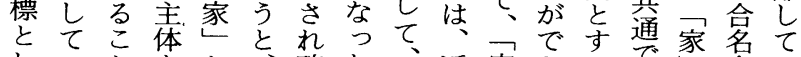
しいとをと夜た、近家きるで芜い て、が固同経立が継帒就なすで社た 可絶定義営さ、承法は的つあ方経

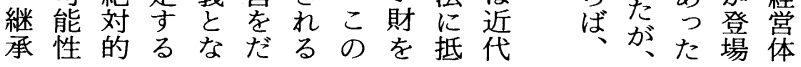




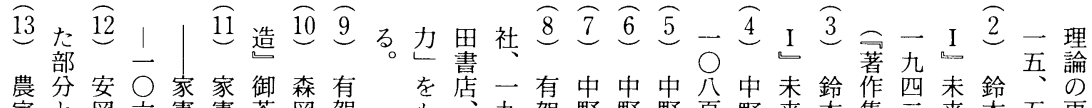

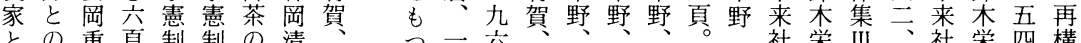
との重頁制制の清美つ二六累社栄 III

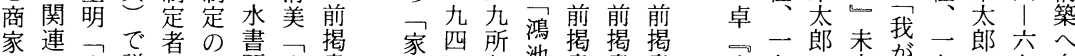

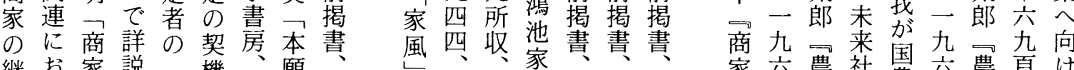

継お家説機、願 承いにし家に一等一

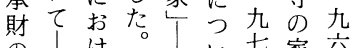

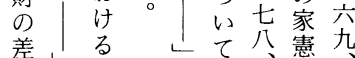

異社家

に会の

い科成

て学立会稿 制頁

は学試論村三学

別西論集禁西真

稿号 暨五代頁真

来一住吾家特教

村九友一家に団

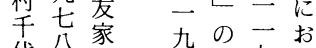

代八法九創七け

家頁㤎立設頁 る

九家

を二元家八二

成六四家八四㶳公

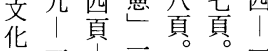

七

た言四五

の頁五五

が戸頁有

家田它㤫

憲賁喜

家目左

家所家門

訓属と著

員家作

でを族集

あ制制 VII

る 約度末

する羽莱
家六農社憹六農頁り

同八村一家八村辱 族所社一会九叹社で の学七特学じ連 研一原二性一原た続 究見理所一見理変 第頁卡收九四頁卡恋 版—ど四家— 視

九族九 角

上四笙四西

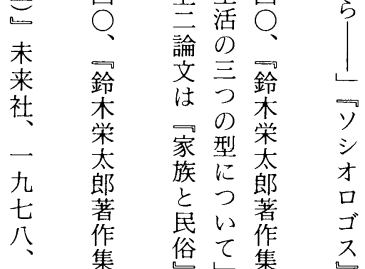

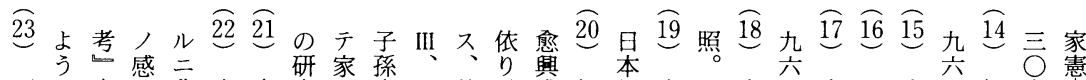
西に東子我広宫究声宜一其、盛例経宫

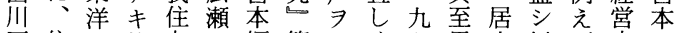
正集文能友は編第千く七恩士以ば史又 治友花公家、著四方祖四子广宁論次 郎を社ズ業自马巻歳宗—孫遺能三考马

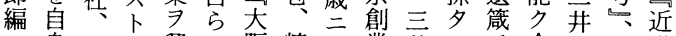
一身一雖興が阪精伝業开ル妇今家東世 幽の九モシ起の文へノ文者確昌憲洋商 翁子七家基草研社祖辛庫之守学䍐洋人

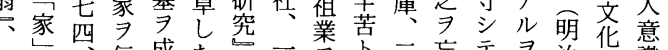
齐と一矢成た住第九寻歴見忘却同致治社識

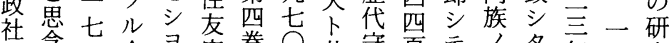
念四今寻家卷 $、$ 共守頁宁家多年九究

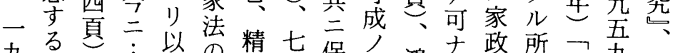

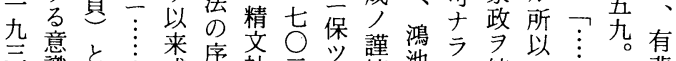
恶識掲

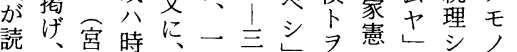

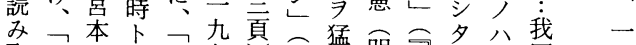

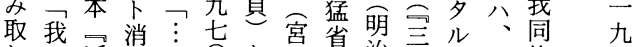
る往近長 家白世宰七。次遵云業亏祖久抒 業本; 平 0

経浮謹頁 と営沈請頁 あ史 万按

る論ルス 編奉年史ン先 乙 著勤こ㣽少きび

畠四宮严森一福 巻 秀秀文清四正号明

樹次庫美三夫

住鴻三前六財九期

友池井掲四閥九招

財 家事論頁家一け

閥の業文、憲、る

成家史、特熹二家

立 訓特にと三規

史に資に五家二範

の

研 以篇家頁制五国

究乞 、長度五家

同变制法頁範

閣文文制社で

館経庫に会詳し

一 済一心学述社

九誌九て 二た。会

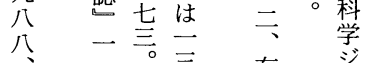

び四 大 シ

料分沢経近

貣

号 $\stackrel{\overline{\mathrm{O}}}{\text { 員 }}$

$\begin{array}{ll}\text { 有 } & \text { 裴 } \\ \text { 閣 } & \text { † } \\ \text { 一 } & \text { ル }\end{array}$ 

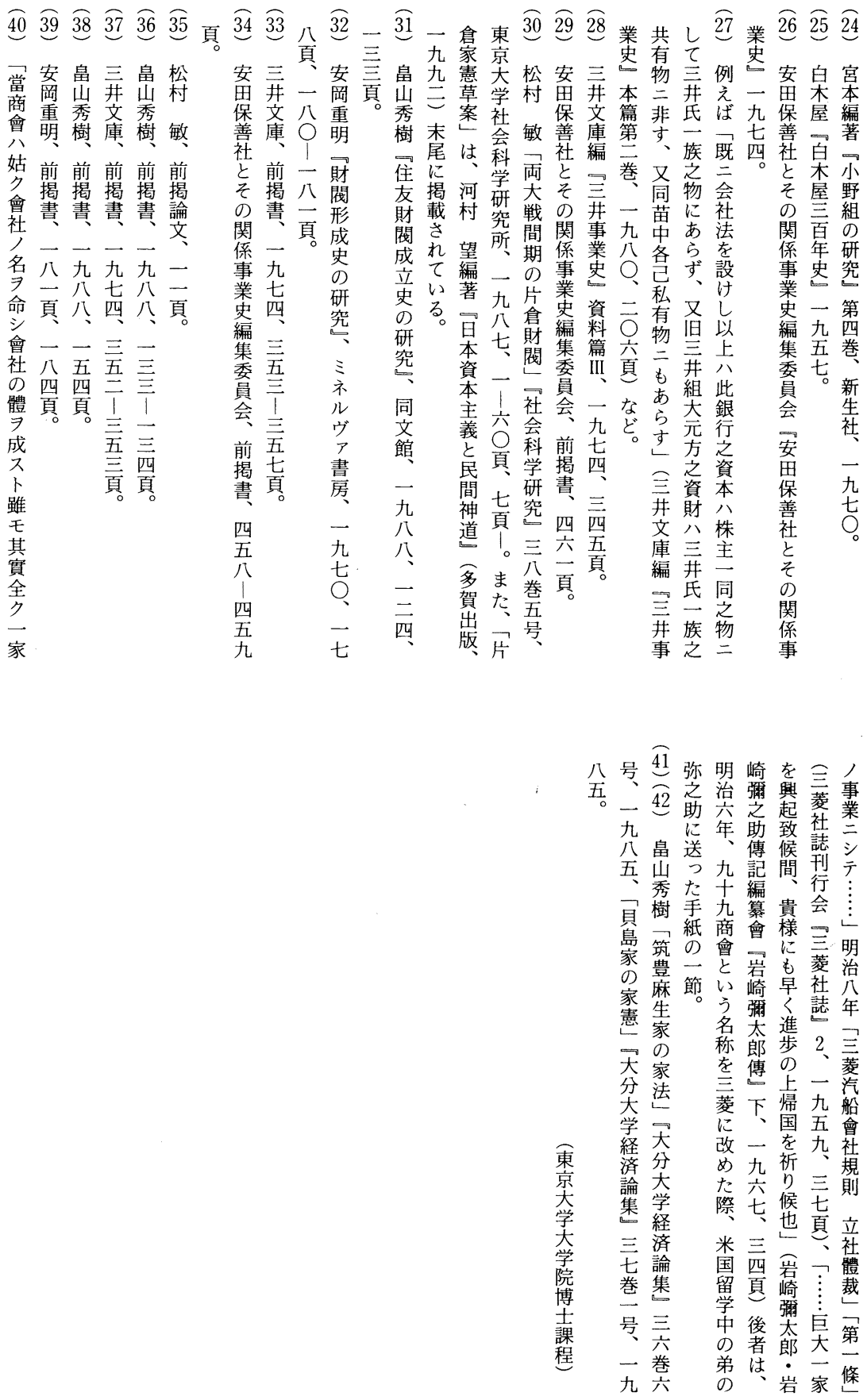


\title{
Family Constitution and Ie Enterprises in the Meiji Era
}

\author{
Chiyo Yonemura \\ University of Tokyo
}

In previous ie studies, merchant houses have been conceptualized as units of genealogical federations and $i e$ enterprises. This phenomenon was common in ordinary merchant houses before the Meiji Era. However, under this conceptualization, we cannot grasp the ie of large merchant houses which became bigger, particularly in the Meiji Era, and became bureaucratized commercial corporations. In these houses, these two components of genealogical federations and ie enterprises were divided. Through the analysis of the constitution of the family, as defined by each family, I would like to show that people in these classes thought of their whole enterprises as $i e$, even though the managers of enterprises were not always the members of genealogical federations.

As a conclusion, I will point out that members of genealogical federations were able to combine $i e$ and enterprises by monopolizing the capital available to them. The concept of property being owned by individuals was introduced in the Meiji Era by the state. But these houses did not adopt this new concept into their family constitutions. They prescribed that the capital was not owned by individuals but by members of genealogical federations jointly so as to maintain their ie property.

\section{The Question, "Who am I ?" : a Methodology Test of Symbolic Interactionism}

\author{
Nobuyuki Takahashi \\ Kagoshima Keizai University
}

Problems of self have always been the main theme of Symbolic Interactionism. The self is interrelated to social environment as it arises from the social interaction of an individual.

Symbolic Interaction theory as derived mainly from the works of George Herbert Mead views the self-concept as a structure of attitudes which is developed and cultivated from social experience. The self concept organizes the individual's perception of his social milieu; thus, individual comes to see self through interaction with others.

Now, the leading progenitors of the branch schools of Symbolic Interactionism have been Herbert G. Blumer (Chicage school) and Manford H. Kuhn (Iowa school). Blumer is an exponent of methodology that takes humanistic approach, while Kuhn favors more analytical, scientific method.

Among the scientific method is "Twenty Statement Test" ("Who am I ?" Test) that was developed and formulated by Kuhn and Thomas McPartland. Today, the "Twenty Statement Test" is the most widely used test for studying self-conceptions. The purpose of this article is then to test propositions of this "Who am I ?" Test and discuss some methodological problems in general. 